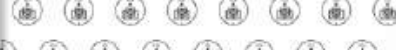

ISSN: 2598-7607 e-ISSN: $2622-223 \mathrm{X}$

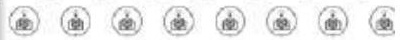
(i) (ii) (i) (i) (i) (i)

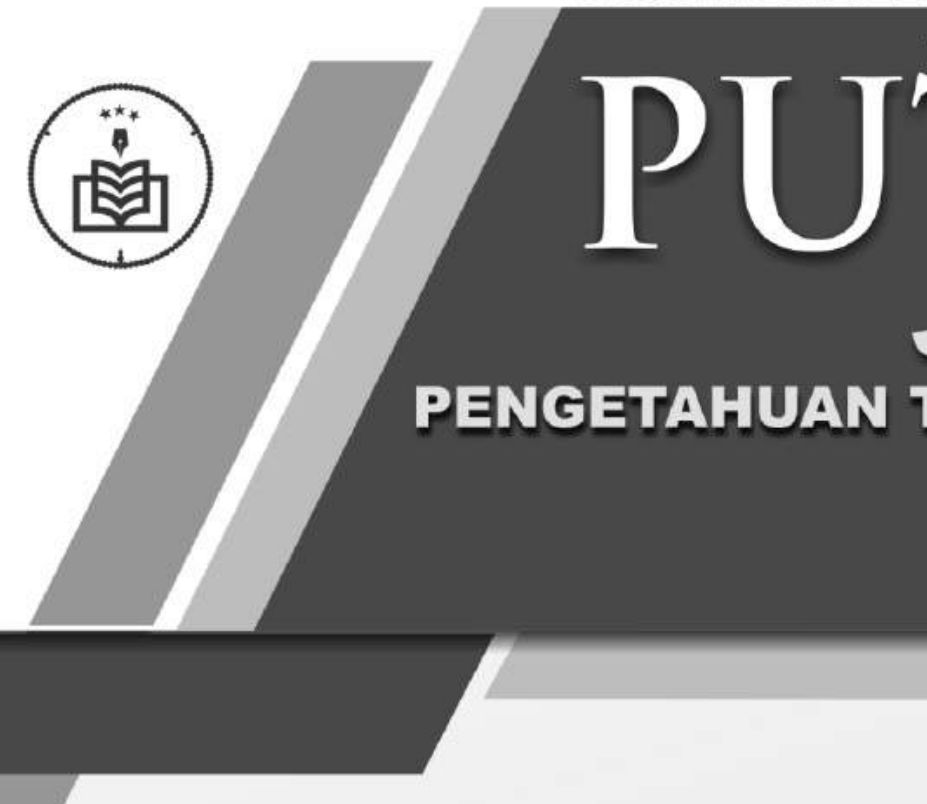

Vol. IV No.2 September 2019

- PRINSIP-PRINSIP BUDAYA SEBAGAI SUMBER HUKUM ISLAM FathurRozi

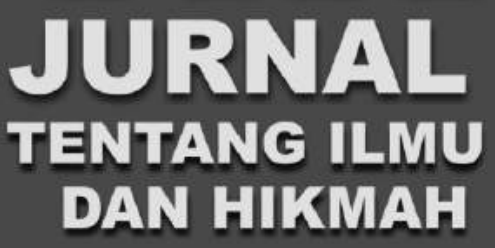
DAN HIKMAH

- Jumlah Anak Ideal dalam Perspektif Hadis

Muzamil

- Mengenal Tafsir Lațā'if al-Isharät Karya al-Qushayrĩ (Kerangka Metodologis dan Kecenderungan Ideologis) Kusroni

- MAHKOTA SINGGASANA DALAM ISTANA SHUFIYAH Kajian Ruang Lingkup Maqomat Dan Ahwal (Pangkat, Derajat dan Kedudukan Para Shufi Di Sisi Allah Swt.) Ahmad Syatori

- PENGARUH QIRA'A $\bar{A}^{\prime}$ MUTAWĀTIRAH DALAM HUKUM FIQH Abu Sari

- AL-ASTIL: PENAFSIRAN AL QURAN DENGAN BAHASA ARAB Fathul Haris

diterbitkan :

MA'HAD ALY

PONDOK PESANTREN ASSALAFI AL FITHRAH Surabaya

2019

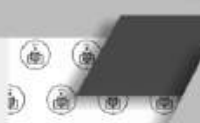

(ii) (iin) (iin)

i.) (i) (i) (i) (i) (i) (i) (4) (4) (4) (4) (4) (4) i) (4) (4) (4) (4) (4) (i) (i) (i) (i) (i)

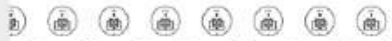
(6) (6) (6) (क) (i) (6) i. (i) (i) (i) (i) (i) (4) (4) (4) (4) (4)

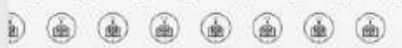

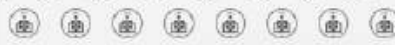

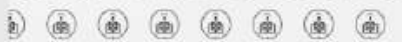

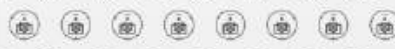
b) (19) (6) (i) (i) (i) (4) (b) (di) (b) (b) (b) b) (6) (4) (4) (b) (4) (b) (i) (4) (6) (b) (b) b) (16) (4) (4) (4) (i) (6) (i) (6) (6) (6) (6) i) (iin) (iin) (in) (in) (in) (6) (6) (6) (6) (6) (6) b) (6) (6) (6) (6) (6) (6) (iin) (6) (6) (6) i) (3) (3) (3) (6)

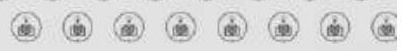

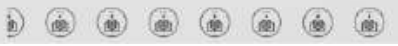




\section{Redaktur PUTIH \\ JURNAL PENGETAHUAN TENTANG ILMU DAN HIKMAH}

Ijin terbit

SK. Mudir Ma'had Aly No. 18/MAy-PAF/II/2018/SK

PEMBINA

Muhammad Musyafa'

Abdur Rosyid

Ahmad Syathori

PENGARAH

Fathur Rozi

PIMPINAN REDAKSI

Fathul Haris

DEWAN EDITOR

Achmad Imam Bashori

\section{ANGGOTA \\ Mustaqim \\ Samsul Arifin \\ Abdul Hadi}

Alamat Penyunting dan Surat Menyurat :

J1. Kedinding Lor 99 Surabaya
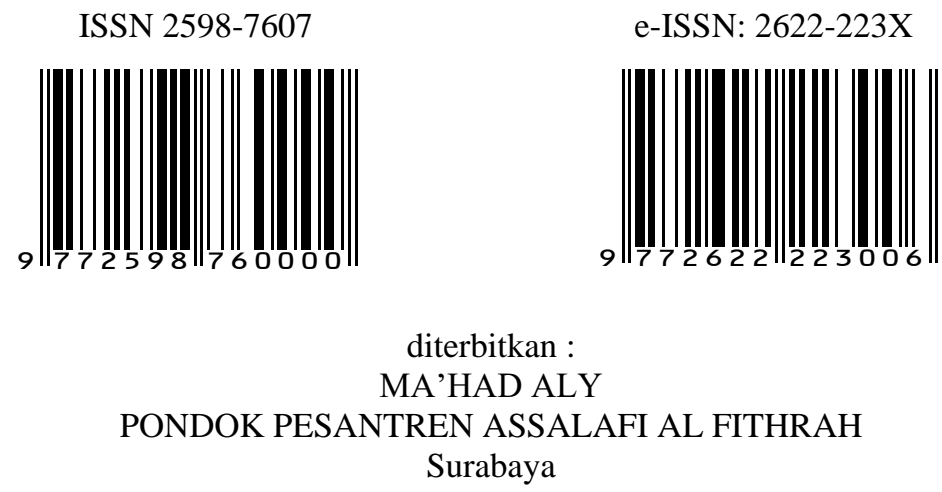


\section{$\underline{\text { Daftar Isi }}$}

- Daftar Isi

- Pedoman Transliterasi

- PRINSIP-PRINSIP BUDAYA SEBAGAI SUMBER HUKUM ISLAM

FathurRozi

- Jumlah Anak Ideal dalam Perspektif Hadis Muzamil

- Mengenal Tafsir Latā'if al-Isharāt Karya al-Qushayrī (Kerangka Metodologis dan Kecenderungan Ideologis) Kusroni

- MAHKOTA SINGGASANA DALAM ISTANA SHUFIYAH

Kajian Ruang Lingkup Maqomat Dan Ahwal (Pangkat, Derajat dan Kedudukan Para Shufi Di Sisi Allah Swt.)

Ahmad Syatori

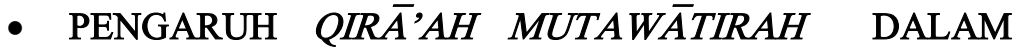
HUKUM FIQH

Abu Sari

- $A L-A S \overline{S I}:$ PENAFSIRAN AL QURAN DENGAN BAHASA ARAB

Fathul Haris 


\section{PEDOMAN TRANSLITERASI}

Berikut ini adalah skema transliterasi Arab-Indonesia yang ditetapkan dalam penulisan jurnal ini:

\begin{tabular}{|c|c|c|c|c|}
\hline $\mathrm{NO}$ & ARAB & INDONESIA & ARAB & INDONESIA \\
\hline 1 & 1 & ' & $b$ & $\mathrm{t}$ \\
\hline 2 & ب & B & ظ & $\mathrm{Z}$ \\
\hline 3 & ت & $\mathrm{T}$ & $\varepsilon$ & 6 \\
\hline 4 & ث & Th & $\dot{\varepsilon}$ & gh \\
\hline 5 & ج & $\mathrm{J}$ & ف & $\mathrm{F}$ \\
\hline 6 & $\tau$ & h & ق & Q \\
\hline 7 & $\dot{\tau}$ & $\mathrm{Kh}$ & 5) & K \\
\hline 8 & د & D & J & $\mathrm{L}$ \\
\hline 9 & j & $\mathrm{Dh}$ & م & $\mathrm{M}$ \\
\hline 10 & J & $\mathrm{R}$ & ن & $\mathrm{N}$ \\
\hline 11 & j & Z & 9 & W \\
\hline 12 & س & $\mathrm{S}$ & هـ & $\mathrm{H}$ \\
\hline 13 & ش & Sh & $s$ & , \\
\hline 14 & ص & $\underline{S}$ & ي & $\mathrm{y}$ \\
\hline 15 & ض & $\underline{\mathrm{d}}$ & & \\
\hline
\end{tabular}

Untuk menunjukkan bunyi hidup panjang (madd) dengan cara menuliskan coretan horizontal di atas huruf $\bar{a}, \bar{i}$ dan $\bar{u}$ (أو، إِئ $\left.1 i_{6}\right)$. 


\title{
PRINSIP-PRINSIP BUDAYA \\ SEBAGAI SUMBER HUKUM ISLAM
}

\author{
Oleh \\ FathurRozi \\ STAI Al Fithrah Surabaya \\ arroziani@gmail.com
}

\section{Abstrak}

Tulisan ini menguraikan tentang 'Urf atau tradisi yang merupakan suatu sumber hukum islam, yang digunakan oleh ulama Mazhab Hanafi dan Maliki, 'urf merupakan salah satu kaidah yang berada diruang lingkup nas. ' Urf adalah bentuk-bentuk mu'āmalah yang telah menjadi adat kebiasaan dan telah berlangsung lama di tengah masyarakat. Dengan menggunakan kaidah ini, berarti kita mengaitkan antara hukum Islam dengan budaya lokal. Namun tradisi atau budaya lokal, tidak sepenuhnya diterima oleh shara' sebagai sesuatu ketetapan hukum yang berlaku, karena di satu sisi mungkin ada tradisi yang justru bertentangan dengan pokok-pokok ajaran Islam dan di sisi lain ada tradisi-tradisi yang tidak bertentangan dengan ajaran Islam. Oleh karena itulah tulisan ini akan membahas prinsip-prinsip budaya sebagai sumber hukum Islam, Alasan tekstual dan rasional bagi penerimaan aspek-aspek lokalitas dalam hukum Islam, serta mekanisme penerimaan hukum Islam terhadap kekayaan budaya, tradisi atau praktek lokal. Untuk menerima dan mengakui tradisi atau budaya lokal, hukum Islam memiliki prinsip-prinsip tertentu yang harus dipenuhi oleh tradisi tersebut, yaitu: 'Urf itu termasuk 'urf yang șahìh, dalam artian tidak bertentangan dengan ajaran al-Qur'an dan Sunnah Rasulullah SAW. 'Urf itu mengandung kemaslahatan dan logis. 'Urf itu harus sudah ada ketika terjadinya suatu peristiwa yang akan dilandaskan kepada 'urf itu. 'Urf itu berlaku umum pada masyarakat yang terkait dengan lingkungan 'urf. Tidak ada ketegasan dari pihak-pihak terkait yang berlainan dengan kehendak 'urf tersebut, sebab jika kedua pihak yang berakad telah sepakat untuk tidak terikat dengan kebiasaan umum yang berlaku, maka yang dipegang adalah ketegasan itu, bukan 'urf.

Kata Kunci : Budaya, Sumber, Hukum Islam 


\section{Latar Belakang Masalah}

Berkaitan dengan tema tentang hukum Islam dan budaya lokal, tentunya kita perlu mengingat kembali bahwa sumber-sumber pokok yang digunakan oleh ulama ushul fikih dalam menggali hukum Islam dan disepakati oleh jumhur ulama, yakni: Al-Qur'an, Hadis, Ijma' dan Qiyas. Di samping empat sumber utama tersebut ada beberapa kaidah yang diterapkan oleh para ulama, diantaranya: 'Urf, Istiṣhāb, Sadd al-Dharāi', Mașālih Mursalah dan lain sebagainya.

' $U r f$ atau tradisi, adalah merupakan suatu sumber hukum yang digunakan oleh ulama Mazhab Hanafi dan Maliki, 'urf merupakan salah satu kaidah yang berada diruang lingkup naș. 'Urf adalah bentuk-bentuk mu'āmalah yang telah menjadi adat kebiasaan dan telah berlangsung lama di tengah masyarakat. Dengan menggunakan kaidah ini, berarti kita mengaitkan antara hukum Islam dengan budaya lokal.

Landasan tekstual diterimanya aspek-aspek lokalitas dalam hukum Islam, dalilnya bersumber dari al-Qur'an dalam surat al-Nisa (4: 115) dan surat al-A'raf (7: 199). Adapun alasan rasional penerimaan tradisi budaya diantaranya, karena syari'at telah diturunkan dengan tujuan mewujudkan kemaslahatan bagi umat manusia, dan termasuk yang mencerminkan kemaslahatan adalah hendaknya diperhatikan tradisi budaya.

Tradisi atau budaya lokal, tidak sepenuhnya diterima oleh shara' sebagai sesuatu ketetapan hukum yang berlaku, karena di satu 
sisi mungkin ada tradisi yang justru bertentangan dengan pokokpokok ajaran Islam dan di sisi lain ada tradisi-tradisi yang tidak bertentangan dengan ajaran Islam. Oleh karena itulah tulisan ini akan membahas konsep 'urf dan 'ādah dalam hukum Islam, Alasan tekstual dan rasional bagi penerimaan aspek-aspek lokalitas dalam hukum Islam, serta mekanisme penerimaan hukum Islam terhadap kekayaan budaya, tradisi atau praktek lokal.

\section{Konsep 'Urfdan 'Ãdah}

Secara etimologi, "urf atau al- 'urfu artinya "yang baik". Para ulama ushul fikih membedakan antara 'ādah dan 'urf dalam menjelaskan posisinya sebagai salah satu dalil untuk menetapkan suatu hukum Islam. Dalam ushul fikih, 'ādah didefinisikan sebagai berikut: ${ }^{1}$

$$
\text { الأمر المتكرر من غير علاقة عقلية }
$$

"Sesuatu yang dikerjakan secara berulang-ulang tanpa adanya hubungan rasional"

Definisi tersebut menjelaskan bahwa jika suatu perbuatan dilakukan berulang-kali menurut hukum akal, maka tidak bisa disebut sebagai 'ādah. Pengertian ini juga menunjukkan bahwa 'ādah itu meliputi persoalan yang sangat luas, yang berkaitan dengan permasalahan pribadi, misalnya kebiasaan sesorang dalam hal tidur, makan, olahraga, atau perkara yang menyangkut orang

1 Ahmad Fahmi Abu Sunnah, al-'Urf wa al-'Ãdah fi Ra'yi al-Fuqahā', (Mesir: Dar al-Fikr al-'Arabi, th...), 8. 
banyak. ' $\tilde{A} d a h$ bisa juga terjadi secara alamiah, seperti cepatnya seorang anak menjadi baligh di daerah-daerah yang tropis dan kelambatan balighnya anak di daerah-daerah yang dingin. 'Ãdah juga bisa bersumber dari hawa nafsu dan kerusakan akhlak, seperti budaya korupsi yang merajalela, begitupula ' $\bar{a} d a h$ bisa terjadi karena pengaruh budaya asing, yang mengakibatkan perubahan budaya suatu daerah. ${ }^{1}$

Adapun definisi 'urf menurut ulama ushul fikih, adalah sebagai berikut: ${ }^{2}$

$$
\text { عادة جمهور قوم في قول أو فعل }
$$

"Kebiasaan mayoritas kaum baik dalam hal perkataan maupun perbuatan"

Berdasarkan definisi tadi, seorang guru besar fikih di Jordania, yakni Musthafa Ahmad al-Zarqa' mengatakan bahwa 'urf merupakan bagian dari 'àdah, karena 'ādah itu lebih umum dibanding 'urf. Menurutnya, 'urf harus berlaku pada mayoritas orang di daerah tertentu, bukan hanya pada pribadi atau golongan tertentu dan 'urf bukanlah suatu kebiasaan yang alami sebagaimana yang terjadi dalam kebanyakan 'ādah, tetapi 'urf muncul dari suatu pemikiran dan pengalaman. Misalnya, kebiasaan mayoritas masyarakat pada daerah tertentu dalam prosesi pernikahan,

${ }^{1}$ Nasrun Haroen, Ushul Fiqh 1, (Jakarta: Logos Wacana Ilmu, Cet. 2, 1997), 138.

2 Abdul Aziz al-Khayyath, Nazariyyat al-'Urf ('Amman: Maktabah alAqsha, tth...), 24. 
bahwasanya untuk memenuhi keperluan rumah-tangga biasa diambil dari mas kawin yang diberikan suami dan takaran tertentu yang digunakan suatu daerah dalam jual-beli makanan. ${ }^{1}$

Konsep 'urf dan 'ādah dalam al-qawā'id al-fiqhiyyah, yang disebut pada kaidah kelima, bunyi teksnya adalah: العادة محكمة " Adat kebiasaan dapat ditetapkan sebagai hukum " Dalam perspektif alqawā 'id al-fiqhiyyah, keduanya memiliki satu makna, yakni lafadz yang mutarādif. 'urf adalah suatu perbuatan yang jiwa merasa tenang melakukannya, karena sejalan dengan akal sehat dan diterima oleh tabiat yang baik. 'Urftidak terjadi kecuali dalam hal yang telah dikenal oleh seluruh masyarakat, yakni al- 'urf 'àm, dan juga terjadi dalam perkara yang sudah dikenal oleh negara atau daerah tertentu, yakni al-'urf al-khāṣ.

Adapun 'ādah adalah, suatu hal yang telah terbiasa dilakukan oleh orang-orang Islam, dan kebiasaan yang dilakukan oleh suatu daerah, negara, atau suku, dan juga hal yang terbiasa dilakukan oleh seseorang. Misalnya, 'ãdah atau kebiasaan perempuan dalam haid dan nifasnya. Maka bisa disimpulkan bahwa, pada dasarnya keduaduanya sama, intinya adalah sesuatu yang jiwa merasa tenang melakukannya dan hal itu diterima oleh akal yang sehat, oleh karena itu tidak ada perbedaan antara keduanya. ${ }^{2}$

Abdul Mun'im Saleh, dalam bukunya yang berjudul "Hukum

${ }^{1}$ Nasrun Haroen, Ushul Fiqh 1, 138-139.

2 Abdul Aziz Muhammad Azzam, al-Qawā 'id al-Fiqhiyyah (Kairo: Dar alHadis, 2005), 172-173. 
Manusia Sebagai Hukum Tuhan" mengatakan bahwa, pada prinsipnya istilah 'urfdan 'ādah mempunyai maksud yang sama, hal ini ditunjukkan oleh rincian dari gagasan ini, sebagaimana terdapat pada kaidah kelima Bab 1, yakni: العادة محكمة, satu-satunya kaidah cabang dari kaidah utama ini adalah:

كل ما ورد باه الشرع مطلقا ولا ضابط له فياه ولا في اللغة يرجع فياء إلى العرف "Setiap ketentuan yang diberikan shara' tanpa pembatasan dan tidak disebutkan kriteria di dalamnya maupun di dalam istilah bahasa, maka dikembalikan kepada 'urf".

Menurutnya, kedua kaidah ini baik kaidah yang pokok maupun cabangnya, memaksudkan ide yang sama, yakni menghargai praktik lokal sebagai perwujudan dari rasa keadilan masyarakat setempat. Hukum Islam mengindahkannya atas dasar perintah tuhan sebagaimana disebutkan dalam surat al-A'raf, ayat 199 dan landasan tekstual lainnya. Kedua kaidah serumpun ini (induk kaidah dan anak cabangnya) menggunakan dua istilah yang berbeda yaitu 'urf dan ‘ādah . Hal ini justru memperkuat pendapat bahwa kedua istilah tersebut bukanlah hal yang berbeda. Lebih lanjut ia mengatakan, tidak menut up kemungkinan pemberian nama yang berbeda tersebut, hanyalah masalah rasa bahasa saja. Jika dalam ushul fikih dipilih nama 'urf, sedangkan dalam al-qawā'id al-fiqhiyyah diberi nama 'ãdah, hal itu berkaitan dengan rasa keindahan redaksional kaidah. 'urf dikaidahkan dalam al-qawā 'id al-fiqhiyyah akan tetapi diganti namanya menjadi 'ādah supaya bunyi redaksi dari kaidah itu memiliki sajak atau keragaman bunyi yang enak didengar. 
Mendengar kata العرف lebih enak daripada mendengar , محكم namun demikian, tidak menutup kemungkinan memang ada perbedaan konsepsi di dalam kedua bidang tersebut. ${ }^{1}$

\section{Perbandingan Umum antara 'Urfdan '‘̄ dah}

1. Dari sisi maknanya, 'àdah mengandung arti pengulangan. Karenanya segala sesuatu yang baru dilakukan satu kali belum dinamakam 'àdah. Namun berapa kali suatu perbuatan harus dilakukan baru disebut 'ādah, tidak pula ada ukuran yang jelas. Sedangkan sesuatu yang dikatakan sebagai 'urf, tidak dilihat dari sisi berulang-kalinya suatu perbuatan dilakukan, tetapi dilihat dari sisi bahwa perbuatan itu telah dikenal, diakui dan diterima oleh orang banyak. ${ }^{2}$

2. 'Urf merupakan bagian dari 'a $d a h$, karena 'àdah itu lebih umum dibanding 'urf. 'Urf harus berlaku pada mayoritas orang di daerah tertentu, bukan hanya pada pribadi atau golongan tertentu dan 'urf bukanlah suatu kebiasaan yang alami sebagaimana yang terjadi dalam kebanyakan 'ādah, tetapi 'urf muncul dari suatu pemikiran dan pengalaman. ${ }^{3}$

3. Pembahasan adat kebiasaan sebagai 'urf dalam ushul fikih ditekankan kepada kedudukannya sebagai hal atau kepantasan

\footnotetext{
${ }^{1}$ Abdul Mun'im Saleh, Hukum Manusia Sebagai Hukum Tuhan: Berpikir Induktif Menemukan Hakikat Hukum Model al-Qawā'id al-Fiqhiyyah (Yogyakarta: Pustaka Pelajar, Cet. 1, 2009), 284-286.

2 Amir Syarifuddin, Ushul Fiqh Jilid 2(Jakarta: Logos, 1999), 363.

${ }^{3}$ Nasrun Haroen, Ushul Fiqh 1, 139.
} 
yang telah secara luas dikenal di dalam masyarakat. Sedangkan dalam al-qawā'id al-fiqhiyyah, kebiasaan sebagai 'ādah ditekankan sebagai hal yang telah terjadi berulang-ulang. Oleh karena itu, pembicaraan tentang 'urf dalam ushul fikih menjelaskan pembagian 'urf dari segi keabsahannya menurut pandangan shara'. Disana 'urf dibagi menjadi 'urf șahīh (legal) dan 'urf făsid(ilegal).

4. Di dalam al-qawā'id al-fiqhiyyah, pembahasan adat kebiasaan lebih rinci sifatnya, tidak demikian hitam putih. Tidak ada istilah șahīh atau făsid, tetapi ada bahasan tentang kebiasaan dengan kriteria konsistensi yang bagaimanakah yang telah dianggap sah untuk menjadi pertimbangan hukum. Di dalam al-qawā'id alfiqhiyyah sudah dianggap maklum jika yang diterima haruslah 'urf șahīh saja. Meskipun demikian, 'urf șahīh masih harus dipertimbangkan dari segi konsistensinya. Ini untuk memastikan apakah telah bisa dianggap sebagai 'ãdah yang sah sebagai pertimbangan hukum ataukah tidak. ${ }^{1}$ Penjelasan lebih lanjut, baca buku "Hukum Manusia Sebagai Hukum Tuhan".

\section{Macam-macam 'Urf}

Para ulama ushul fikih membagi 'urf menjadi tiga macam:

1. Dari segi objeknya, 'urfterbagi menjadi al-'urf al-laf̧̧i $i$ (kebiasaan yang berkaitan dengan ungkapan) dan al-'urf al-'amali (kebiasaan

\footnotetext{
${ }^{1}$ Abdul Mun'im Saleh, Hukum Manusia Sebagai Hukum Tuhan, 286-287.
} 
yang berbentuk perbuatan).

a. Al-'urf al-lafzi, adalah kebiasaan masyarakat dalam mempergunakan lafadz tertentu dalam mengucapkan sesuatu, sehingga makna ucapan itulah yang dipahami dan terlintas dalam pikiran masyarakat. Misalnya, ungkapan "daging" yang berarti daging sapi: padahal kata-kata "daging" meliputi seluruh daging yang ada. Apabila seseorang mendatangi penjual daging, sementara penjual daging itu memiliki bermacam-macam daging, lalu pembeli mengatakan "saya beli daging satu kilogram", pedagang itu langsung mengambilkan daging sapi, karena kebiasaan masyarakat setempat telah mengkhususkan penggunaan kata daging pada daging sapi.

b. Al-'urf al-'amali, adalah kebiasaan masyarakat yang berkaitan dengan perbuatan biasa. Yang dimaksud "perbuatan biasa" adalah perbuatan masyarakat dalam masalah kehidupan mereka yang tidak terkait dengan kepentingan orang lain, seperti kebiasaan libur kerja pada hari-hari tertentu dalam satu minggu, kebiasaan masyarakat tertentu memakan makanan dan meminum minuman khusus atau memakai pakaian tertentu dalam acara-acara tertentu. ${ }^{1}$

2. Dari segi cakupannya, 'urf terbagi dua, yakni al-'urf al- ‘amm (kebiasaan yang bersifat umum) dan al-'urf al-khāṣ (kebiasaan yang bersifat khusus).

a. Al-'urf al- 'àm, adalah kebiasaan tertentu yang berlaku secara

${ }^{1}$ Nasrun Haroen, Ushul Fiqh 1, 139-140. 
luas diseluruh masyarakat ataupun daerah. Contoh, kebiasaan yang berlaku pada negara-negara tertentu mengenai ungkapan talak terhadap istri, seperti pernyataan "engkau telah haram aku gauli”. Apabila ungkapan ini telah diucapkan oleh suami terhadap istrinya, suami dianggap telah menjatuhkan talak kepada istrinya. Begitupula kebiasaan menyewa kamar mandi umum dengan jumlah sewa tertentu, tetapi tidak ditetapkan secara pasti lamanya waktu mandi dan kadar air yang digunakan. ${ }^{1}$

b. Al-'urf al-khāṣ, adalah kebiasaan yang berlaku di daerah dan masyarakat tertentu. Misalnya, di kalangan para pedagang, apabila terdapat cacat tertentu pada barang yang dibeli dapat dikembalikan. Contoh lain, adalah kebiasaan yang berlaku dikalangan pengacara hukum bahwa jasa pembelaan hukum yang akan dia lakukan harus dibayar dahulu sebagian oleh kliennya. Menurut Musthafa Ahmad al-Zarqa', 'urf ini tidak terhitung jumlahnya dan senantiasa berkembang sesuai dengan perubahan situasi dan kondisi masyarakat. ${ }^{2}$

3. Dari segi keabsahannya dalam pandangan shara', 'urfterbagi dua, yaitu: al-'urf al-șahìh (kebiasaan yang dianggap sah atau benar) dan al-'urf al-făsid (kebiasaan yang dianggap rusak atau tidak benar).

${ }^{1}$ Firdaus, Ushul Fiqh: Metode Mengkaji dan Memahami Hukum Islam Secara Komprehensif(Jakarta: Zikrul Hakim, Cet. 1, 2004), 98.

${ }^{2}$ Nasrun Haroen, Ushul Fiqh 1, 140-141. 
a. Al-'urf al-ṣahīh, adalah kebiasaan yang berlaku ditengahtengah masyarakat, yang mana tidak bertentangan dengan alnaș (al-Qur'an atau hadis), tidak menghilangkan kemaslahatan mereka dan tidak pula membawa mudharat bagi mereka. Misalnya, dalam masa pertunangan pihak laki-laki memberikan hadiah kepada pihak wanita, dan hadiah ini tidak dianggap sebagai bagian dari mahar.

b. Al-'urf al-fâsid, kebiasaan yang bertentangan dengan dalildalil shara' dan kaidah-kaidah dasar yang ada dalam shara'. Misalnya, sogok-menyogok atau suap-menyuap. Untuk memenangkan perkaranya, seseorang menyerahkan sejumlah uang kepada hakim, atau untuk kelancaran urusan yang dilakukan seseorang, ia memberikan sejumlah uang kepada orang yang menangani urusannya. ${ }^{2}$ Contoh lain, menyajikan minuman memabukkan pada acara-acara resmi, atau mengadakan tarian-tarian wanita yang berpakaian seksi dan mempertontonkan aurat pada acara yang dihadiri perserta laki-laki. $^{3}$

\section{Kedudukan 'Urf sebagai Metode Istinbāt Hukum Islam}

Para ulama ushul fikih sepakat bahwa, 'urf șahìh yang tidak

\footnotetext{
${ }^{1}$ Abdul Wahhab Khallaf, 'Ilmu UșūI al-Fiqh, terj. Noer Iskandar al-Barsany dan M. Tholhah Mansur (Jakarta: PT RajaGrafindo Persada, Cet. 8, 2002), 131.

${ }^{2}$ Nasrun Haroen, Ushul Fiqh I, 141.

3 Satria Effendi, M. Zein, Ushul Fiqh (Jakarta: Prenada Media, Cet. 1, 2005), 155.
} 
bertentangan dengan shara', baik yang menyangkut 'urf al- 'âm dan 'urf al-khās, maupun yang berkaitan dengan 'urf al-laf̧̣i dan 'urf al'amali, dapat dijadikan sebagai hujjah dalam menetapkan hukum shara'.

Menurut Imam al-Qarafi, ahli fikih Maliki (w. 684 H/ 1285 M), ${ }^{1}$ Seorang mujtahid dalam menetapkan suatu hukum, harus terlebih dahulu meneliti kebiasaan yang berlaku dalam masyarakat setempat, sehingga hukum yang ditetapkan itu tidak bertentangan atau menghilangkan kemaslahatan yang menyangkut masyarakat tersebut. Menurut Imam al-Syatibi, ahli ushul fikih Maliki (w. 790 H) dan Imam Ibn Qayyim al-Jauziyyah, ahli ushul fikih Hambali (691-751 H/ 1292-1350 M), seluruh ulama mazhab menerima dan menjadikan 'urf sebagai dalil shara' dalam menetapkan hukum, apabila tidak ada nas yang menjelaskan hukum suatu masalah yang dihadapi. Misalnya, seseorang yang menggunakan jasa pemandian umum dengan harga tertentu, padahal lamanya ia dalam kamar mandi itu dan berapa jumlah air yang terpakai tidak jelas. Sesuai dengan ketentuan umum syari'at Islam dalam suatu akad, kedua hal ini harus jelas adanya. Akan tetapi, perbuatan seperti ini telah berlaku luas di tengah-tengah masyarakat, sehingga seluruh ulama mazhab menganggap sah akad ini. Alasan mereka adalah 'urf al'amali yang berlaku.

Para ulama juga sepakat menyatakan bahwa ketika ayat-ayat

${ }^{1}$ Syihabuddin Ahmad ibn Idris al-Qarafi, Anwār al-Barūq fỉ Anwā' alFurūq Jilid III (Mesir: Dar al-Ihya' al-Kutub al-'Arabiyyah, 1344 H, 49. 
al-Qur'an diturunkan, banyak sekali ayat-ayat yang mengukuhkan kebiasaan yang terdapat di tengah-tengah masyarakat. Misalnya, kebolehan jual-beli yang sudah ada sebelum Islam. Hadis-hadis Rasulullah SAW Juga banyak sekali yang mengakui eksistensi 'urf yang berlaku di tengah masyarakat, seperti hadis yang berkaitan dengan jual-beli pesanan (salam). Dalam sebuah riwayat dari Ibn Abbas dikatakan bahwa, ketika Rasulullah SAW hijrah ke Madinah, beliau melihat penduduk setempat melakukan jual beli salam tersebut. lalu Rasulullah SAW bersabda:

$$
\text { من أسلف في تمر فليسلف في كيل معلوم ووزن معلوم إلى أجل معلوم }
$$

"Barang siapa yang melakukan jual-beli salam pada kurma, maka hendaklah ditentukan jumlahnya, takarannya, dan tenggang waktunya" (HR. al-Bukhari).

Dari berbagai kasus yang dijumpai, para ulama ushul fikih merumuskan kaidah-kaidah fikih yang berkaitan dengan 'urf, diantaranya adalah yang paling mendasar:

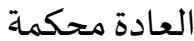

"Adat kebiasaan itu bisa ditetapkan menjadi hukum".

$$
\text { لا ينكر تغير الأحكام بتغير الأزمنة والأمكنة }
$$

"Tidak bisa dipungkiri perubahan hukum disebabkan perubahan zaman dan tempat".

$$
\text { الثابت بالعرف كالثابت بالنص }
$$

"Sesuatu yang ditetapkan berdasarkan 'urf sama halnya dengan perkara yang ditetapkan berdasarkan nash (ayat dan atau hadis). ${ }^{1}$

1 Jalaluddin Abd al-Rahman al-Suyuthi, al-Ashbāh wa al-Nazā 'ir (Beirut: Muassasat al-Kutub al-Tsaqafiyyah, cet. 2, 1996) 80,88. 


\section{Alasan Tekstual dan Rasional Penerimaan 'Urfdan 'Ãdah}

Landasan diterimanya aspek-aspek lokalitas atau tradisi dalam hukum Islam, adalah :

1. Abdul Aziz Muhammad Azzam mengutip dari buku "al-Fawā 'id al-Janiyyah 'Alā al-Mawāhib al-Saniyyah" bahwasanya, dianggapnya 'ādah sebagai hujjah dalam menetapkan hukum Islam, dalilnya bersumber dari firman Allah SWT:

$$
\begin{aligned}
& \text { ومن يشاقق الرسول من بعد ما تبين له الهدى ويتبع غير سبيل المؤمنين } \\
& \text { نوله ما تولى ونصيله جهنم وساءت مصيرا (النساء: } 10 \text { (1) ). }
\end{aligned}
$$

Yang dijadikan dalil dalam ayat ini adalah: makna dari kata "alSabil”, yakni “jalan”, maka jalannya orang-orang mukmin adalah kebiasaan-kebiasaan mereka yang dianggap baik, dan Allah SWT telah memberikan ancaman bagi mereka yang tidak mengikuti jalan orang-orang mukmin, maka ini menunjukkan bahwa mengikuti jalan orang-orang mukmin itu wajib. ${ }^{1}$

2. Abdul Karim Zaidan mengatakan, sebagian ulama yang menjadikan 'urf sebagai salah satu landasan untuk menetapkan hukum Islam berpendapat, bahwasanya Allah SWT telah berfirman dalam al-Qur'an:

$$
\text { خذ العفو وأمر بالعرف وأعرض عن الجاهلين (الأعراف: } 99 \text { 1) }
$$

Menurutnya, hujjah ini lemah karena yang dimaksud dengan kata 'urf dalam ayat tersebut adalah "yang telah dikenal atau diketahui", yakni yang telah diketahui kebaikannya dan wajib

\footnotetext{
${ }^{1}$ Abdul Aziz Muhammad Azzam, al-Qawā 'id al-Fiqhiyyah, 173.
} 
melaksanakannya, dengan kata lain setiap apa yang diperintahkan oleh syari'at. ${ }^{1}$

3. Disebutkan dalam kitab "al-Ashbāh wa al-Nazā 'ir" bahwasanya, asas dari kaidah ini adalah perkataan Ibnu Mas'ud R.A. :

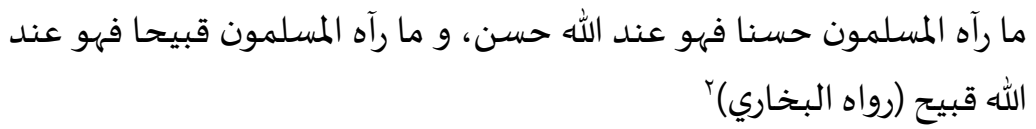

Al-'Alai berkata: Aku tidak mendapatkannya marfú' dalam kitab-kitab hadis dan tidak pula dengan sanad yang lemah, setelah mengkaji dan meneliti lebih detail, didapatkan bahwasanya hadis tersebut mauqū $f$ dari Abdullah bin Mas'ud, hal ini disebutkan oleh Imam Ahmad dalam kitab "Musnad". ${ }^{3}$

Walaupun demikian hadis itu maknanya benar dan sesuai dengan yang diminta, apakah diriwayatkan marfü' kepada Nabi Muhammad SAW atau mawqū $f$ atas Ibnu Mas'ud R.A., karena keterangan hadis mengisyaratkan bahwa maksud dari pada kata "muslimīn" dalam hadis tersebut adalah sahabat, ulama-ulama salaf dan khalaf. Hal ini dipahami dari kata-kata al-Amidi, Ibnu Hazm dan Syatibi dalam kitab "al-I'tișām”, yang mengatakan: bahwasanya, kata "muslimīn" adalah merupakan sighah "umum dan huruf lamnya adalah $\hbar$ il al-istighrā $q$ yang menunjukkan ijma'

\footnotetext{
1 Abdul Karim Zaidan, al-Waj̄z Fì Ușūl al-Fiqhi (Beirut: Muassasat alRisalah, Cet. 4, 1994), 254.

2 Jalaluddin Abd al-Rahman al-Suyuthi, al-Ashbāh wa al-Nazā 'ir, 119. Muhammad Abu Zahroh, Ușūl al-Fiqh (Beirut: Dar al-Fikr al-'Arabi, tth...), 273.

3 Amir Abdul Aziz, Ușūl al-Fiqhi al-Islāmiy, al-Mujallad II (Mesir: Dar alSalam, Cet. 1, 1997), 503.
} 
ahl al-hill wa al-'aqd, dan apa-apa yang dianggap mereka baik, maka bagi Allah itu baik, dengan makna ini bisa dijadikan sebagai hujjah.

4. Para ulama telah bersepakat bahwa, tradisi atau kebiasaan bisa dijadikan sebagai hukum dalam hal-hal yang telah berulangberulang dilakukan menurut adat kebiasaan, karena itu terlahir dari hajat dan kemaslahatan yang tidak bertentangan dengan nușuṣs al-shar'i dan tujuan-tujuan umumnya. Kadang-kadang masyarakat pada zaman nabi SAW terbiasa melakukan suatu perkara yang berkaitan dengan perihal kehidupan mereka dan Nabi tidak mengharamkan hal itu, ini membuktikan hal tersebut boleh dilakukan. Maka adat atau tradisi merupakan landasan hukum dalam perkara-perkara yang baru pada setiap zaman dan tempat. $^{1}$

5. Syari'at telah diturunkan dengan tujuan mewujudkan kemaslahatan-kemaslahatan bagi hamba-hambanya, dan termasuk yang mencerminkan kemaslahatan adalah, hendaknya diperhatikan tradisi dan kebiasaan mereka yang disenangi, yakni tradisi atau kebiasaan yang mereka lakukan dan menganggapnya baik dan mereka sukai. Oleh karenanya, sewajarnya 'urf itu dianggap dan diakui sebagai salah satu sumber dari sumbersumber hukum Islam, dengan catatan harus ada ketentuanketentuan dan syarat-syarat tertentu, yang menjadikannya justru

${ }^{1}$ Abdul Aziz Muhammad Azzam, al-Qawā 'id al-Fiqhiyyah, 173-174. 
tidak bertentangan dengan ajaran Islam. ${ }^{1}$

Imam al-Suyuthi dalam kitab "al-Ashbāh wa al-Nazā 'ir" dalam hal 'urf mengatakan, "ketahuilah! Diterimanya 'urf dan 'ādah dalam hukum Islam merujuk pada fikih dalam beberapa masalah yang tidak terhitung banyak, diantaranya: umur haid dan baligh. Minimalnya masa haid, nifas dan masa suci dari haid. Masa haid pada umumnya dan maksimalnya, perbuatanperbuatan yang menafikan sholat, najis-najis yang ma'fū kalau sedikit kadarnya, panjang dan pendeknya zaman dalam hal dianggap berkesinambungannya wudhu, khutbah, jum'at, antara ijab dan qabul, memberikan salam dan membalasnya, penangguhan yang menghalangi dikembalikannya barang karena adanya aib/cacat, mengambil atau memakan buah-buahan yang jatuh dari pohonnya, dalam hal al-mu'ātāh sebagaimana pendapat yang dipilih oleh Imam Nawawi, dalam timbangan dan takaran yang belum diketahui keadaannya pada masa Rasulullah SAW, pendapat yang paling șahìh dalam hal ini adalah, dilihat adat kebiasaan negara atau daerah dalam berjual-beli. Dalam perkara melepaskan hewan-hewan ternak pada siang hari dan menjaganya pada malam hari. $^{2}$

\section{Prinsip-Prinsip Budaya Sebagai Sumber Hukum Islam}

Untuk menerima dan mengakui tradisi, kebiasaan, atau

${ }^{1}$ Amir Abdul Aziz, Ușūl al-Fiqhi al-Islāmiy, al-Mujallad II, 507.

2 Jalaluddin Abd al-Rahman al-Suyuthi, al-Ashbāh wa al-Nazā 'ir, 119-120. 
budaya lokal sebagai hujjah atau landasan dalam menetapkan hukum Islam, disyaratkan memenuhi beberapa prinsip, yaitu:

1. 'Urf tersebut termasuk 'urf yang șahīh, dalam artian tidak bertentangan dengan ajaran al-Qur'an dan Sunnah Rasulullah SAW. ${ }^{1}$ Misalnya, kebiasaan di satu negeri atau daerah bahwasanya sah mengembalikan harta titipan atau amanah kepada istri dan anak dari pihak pemberi atau pemilik titipan. Kalau kebiasaannya bertentangan dengan al-nas (al-Qur'an dan Sunnah), maka kebiasaan itu tidak dianggap atau diakui. Seperti kebiasaan ber-mu'āmalah dengan riba, meminum-minuman keras pada acara-acara tertentu, atau membuka aurat dan lain sebagainya. Menurut jumhur ulama, kebiasaan-kebiasaan seperti ini tidak bisa diterima. ${ }^{2}$

2. 'Urf itu mengandung kemaslahatan dan logis. Syarat ini merupakan sesuatu yang mutlak ada pada 'urf yang șahīh sehingga dapat diterima masyarakat umum. Sebaliknya, apabila 'urf itu mendatangkan kemudharatan dan tidak dapat diterima logika, maka 'urf yang demikian tidak dapat dibenarkan dalam Islam. Misalnya, kebiasaan istri yang membakar dirinya hiduphidup bersamaan dengan pembakaran jenazah suaminya yang meninggal. Meskipun 'urf ini dipandang baik dalam suatu msyarakat tertentu, tetapi kebiasaan seperti ini tidak dapat

1 Muchlis Usman, Kaidah-kaidan Istinbath Hukum Islam (Jakarta: PT RajaGrafindo Persada, Cet. 2, 1997), 142.

${ }^{2}$ Abdul Karim Zaidan, al-Waj̄z Fì Ușūl al-Fiqhi, 256. 
diterima oleh akal sehat. ${ }^{1}$

3. 'Urf itu harus sudah ada ketika terjadinya suatu peristiwa yang akan dilandaskan kepada 'urf itu. Misalnya, seseorang yang mewakafkan hasil kebunnya kepada ulama, sedangkan yang disebut ulama waktu itu hanyalah orang yang mempunyai pengetahuan agama tanpa adanya persyaratan memiliki ijazah, maka kata ulama dalam pernyataan wakaf itu harus diartikan dengan pengertiannya yang sudah dikenal itu, bukan dengan pengertian ulama yang menjadi populer kemudian setelah ikrar wakaf itu terjadi, seperti harus punya ijazah. ${ }^{2}$ Contoh lain: mengenai pemberian mahar kepada istri oleh suami. Orang yang melaksanakan akad nikah dan pada saat akad tidak menjelaskan teknis pembayaran maharnya, dalam artian dibayar lunas atau dicicil. Sementara 'urf yang berlaku di tempat itu adalah melunasi seluruh mahar. Ternyata kemudian 'urf di tempat itu mengalami perubahan dan masyarakat telah terbiasa mencicil mahar. Lalu muncul masalah yang menyebabkan terjadinya perselisihan antara suami-istri tentang pembayaran mahar tersebut. suami berpegang pada adat yang berlaku kemudian, yakni dicicil. Sementara istri berpegang pada 'urf yang berlaku pada saat akad nikah dulu. Berdasarkan syarat ini, maka suami harus membayar mahar kepada istrinya dengan lunas, sesuai

${ }^{1}$ Firdaus, Ushul Fiqh: Metode Mengkaji dan Memahami Hukum Islam Secara Komprehensif, 105.

${ }^{2}$ Satria Effendi, M. Zein, Ushul Fiqh, 157. 
dengan 'urf yang berlaku dulu, pada saat akad nikah berlangsung. ${ }^{1}$ Dalam kaidah ushuliyyah disebutkan:

$$
\text { لا عبرة للعرف الطارئ }
$$

"Urf yang datang kemudian tidak dapat dijadikan sandaran hukum terhadap kasus yang telah lama".2

4. 'Urf tersebut berlaku umum pada masyarakat yang terkait dengan lingkungan 'urf, atau minimal di kalangan sebagian besar masyarakat. Syarat ini semakin jelas dengan melihat contoh yang berkembang dalam masyarakat. Umpamanya, umumnya masyarakat di Indonesia dalam melakukan transaksi senantiasa menggunakan alat tukar resmi, yakni mata uang rupiah. Karenanya, dalam suatu transaksi, tidak masalah bila tidak menyebutkan secara jelas tentang jenis mata uangnya, karena semua orang telah mengetahuinya dan tidak ada kemungkinan lain dari penggunaan mata uang rupiah yang berlaku, kecuali dalam kasus tertentu. ${ }^{3}$

5. Tidak ada ketegasan dari pihak-pihak terkait yang berlainan dengan kehendak 'urf tersebut, sebab jika kedua pihak yang berakad telah sepakat untuk tidak terikat dengan kebiasaan yang berlaku umum, maka yang dipegang adalah ketegasan itu, bukan 'urf. Misalnya, adat yang berlaku pada suatu masyarakat, istri

${ }^{1}$ Firdaus, Ushul Fiqh: Metode Mengkaji dan Memahami Hukum Islam Secara Komprehensif, 106.

${ }^{2}$ Abdul Aziz Muhammad Azzam, al-Qawā 'id al-Fiqhiyyah, 190.

${ }^{3}$ Firdaus, Ushul Fiqh: Metode Mengkaji dan Memahami Hukum Islam Secara Komprehensif, 106. 
belum boleh dibawa oleh suaminya pindah dari rumah orangtuanya sebelum melunasi maharnya, namun ketika berakad kedua belah pihak telah sepakat bahwa, sang istri sudah boleh dibawa oleh suaminya pindah tanpa ada persyaratan melunasi maharnya. Dalam kasus ini, yang dianggap berlaku adalah kesepakatan itu, bukan adat yang berlaku. ${ }^{1}$

\section{Kesimpulan}

Konsep 'ādah dalam ushul fikih, adalah Sesuatu yang dikerjakan secara berulang-ulang tanpa adanya hubungan rasional. Adapun 'urf menurut ulama ushul fikih, adalah Kebiasaan mayoritas kaum baik dalam hal perkataan maupun perbuatan.

Konsep 'urf dan 'ādah dalam al-Qawā'id al-Fiqhiyyah, yang disebut pada kaidah kelima, bunyi teksnya adalah: العادة محكمة, keduanya memiliki satu makna, yakni lafadz yang mutarādif, kami lebih cenderung ke pendapat yang mengatakan bahwa, pemberian nama yang berbeda tersebut, hanyalah masalah rasa bahasa saja. Jika dalam ushul fikih dipilih nama 'urf, sedangkan dalam al-qawā' 'id fiqhiyyah diberi nama 'ādah, hal itu berkaitan dengan cita-rasa keindahan redaksional kaidah.

Alasan Tekstual dan Rasional Penerimaan 'Urf dan 'âdah adalah: dalam al-Qur'an disebutkan dalam surat al-Nisaa, ayat: 115 dan surat al-A'raf, ayat: 199. Sedangkan dalam hadis, perkataan

\footnotetext{
${ }^{1}$ Satria Effendi, M. Zein, Ushul Fiqh, 157.
} 
Ibnu Mas'ud yang diriwayatkan oleh Imam Bukhari. Alasan rasionalnya, para ulama telah bersepakat bahwa, tradisi atau kebiasaan bisa dijadikan sebagai hukum dalam hal-hal yang telah berulang-berulang dilakukan menurut adat kebiasaan, karena itu terlahir dari hajat dan kemaslahatan yang tidak bertentangan dengan nușūs al-shar'i dan tujuan-tujuan umumnya. Syari'at telah diturunkan dengan tujuan mewujudkan kemaslahatan-kemaslahatan bagi hamba-hambanya, dan termasuk yang mencerminkan kemaslahatan adalah, hendaknya diperhatikan tradisi dan kebiasaan mereka yang disenangi, dengan catatan harus ada ketentuanketentuan dan syarat-syarat tertentu, yang menjadikannya justru tidak bertentangan dengan ajaran Islam.

Untuk menerima dan mengakui tradisi atau budaya lokal, hukum Islam mensyaratkan adanya syarat-syarat tertentu yang harus dipenuhi oleh tradisi tersebut, yaitu: 'Urf itu termasuk 'urf yang șahìh, dalam artian tidak bertentangan dengan ajaran al-Qur'an dan Sunnah Rasulullah SAW. 'Urf itu mengandung kemaslahatan dan logis. 'Urf itu harus sudah ada ketika terjadinya suatu peristiwa yang akan dilandaskan kepada 'urf itu. 'Urf itu berlaku umum pada masyarakat yang terkait dengan lingkungan 'urf. Tidak ada ketegasan dari pihak-pihak terkait yang berlainan dengan kehendak 'urf tersebut, sebab jika kedua pihak yang berakad telah sepakat untuk tidak terikat dengan kebiasaan umum yang berlaku, maka yang dipegang adalah ketegasan itu, bukan 'urf. 


\section{DAFTAR PUSTAKA}

Azzam Abdul Aziz Muhammad, al-Qawā'id al-Fiqhiyyah. Kairo: Dar al-Hadis, 2005.

Aziz Amir Abdul, Ușūl al-Fiqhi al-Islāmiy, al-Mujallad II. Mesir: Dar al-Salam, Cet. 1, 1997.

Firdaus, Ushul Fiqh: Metode Mengkaji dan Memahami Hukum Islam Secara Komprehensif. Jakarta: Zikrul Hakim, Cet. 1, 2004.

Haroen Nasrun, Ushul Fiqh 1. Jakarta: Logos Wacana Ilmu, Cet. 2, 1997.

Khallaf Abdul Wahhab, Ilmu Ușūl al-Fiqh, terj. Noer Iskandar al-Barsany dan M. Tholhah Mansur. Jakarta: PT RajaGrafindo Persada, Cet. 8, 2002.

Khayyath (al) Abdul Aziz, Nazariyyat al-'Urf. 'Amman: Maktabah al-Aqsha, tth...

Qarafi (al) Syihabuddin Ahmad ibn Idris, Anwār al-Barūq fi Anwā' al-Fuñ q Jilid III. Mesir: Dar al-Ihya' al-Kutub al'Arabiyyah, $1344 \mathrm{H}$.

Saleh Abdul Mun'im, Hukum Manusia Sebagai Hukum Tuhan: Berpikir Induktif Menemukan Hakikat Hukum Model alQawā 'id al-Fiqhiyyah. Yogyakarta: Pustaka Pelajar, Cet. $1,2009$.

Sunnah Ahmad Fahmi Abu, al-'Urf wa al-'Âdah fi Ra'yi alFuqahō'. Mesir: Dar al-Fikr al-'Arabi, tth...

Suyuthi (al) Jalaluddin Abd al-Rahman, al-Ashbāh wa alNaz̄ā 'ir. Beirut: Muassasat al-Kutub al-Tsaqafiyyah, cet. 2, 1996.

Syarifuddin Amir, Ushul Fiqh Jilid 2. Jakarta: Logos, 1999. 
Usman Muchlis, Kaidah-kaidan Istinbath Hukum Islam. Jakarta: PT RajaGrafindo Persada, Cet. 2, 1997.

Zahroh Muhammad Abu, Ușūl al-Fiqh. Beirut: Dar al-Fikr al'Arabi, tth...

Zaidan Abdul Karim, al-Waj̄z Fì Ușūl al-Fiqhi. Beirut: Muassasat al-Risalah, Cet. 4, 1994.

Zein Satria Effendi M., Ushul Fiqh. Jakarta: Prenada Media, Cet. 1, 2005. 